\title{
Leaf and whole-plant water relations of the Patagonian conifer Austrocedrus chilensis (D. Don) Pic. Ser. et Bizzarri: implications on its drought resistance capacity
}

\author{
Javier E. GYENGE*, María Elena FERnÁNDEZ, Guillermina DALla SALDA, Tomás Schlichter \\ INTA Estación Experimental Agropecuaria Bariloche, CC 277, 8400 San Carlos de Bariloche, Argentina
}

(Received 5 May 2004; accepted 18 October 2004)

\begin{abstract}
Physiological studies have suggested that A. chilensis would survive during drought avoiding water stress through an early stomatal closure. However, there are no studies that have explored other potential mechanisms related to drought resistance or avoidance. The objectives were: (1) to measure hydraulic resistance, vulnerability to cavitation and leaf water relations, and (2) to compare these characteristics between different provenances. Pressure-volume curves demonstrate that A. chilensis has high osmotic potentials at full turgor, high water potentials at turgor loss point, low modulus of elasticity, and did not present elastic or osmotic adjustments after drought. Compared to other gymnosperms, A. chilensis has a high total plant resistance but also a high vulnerability to cavitation. We found no differences between the studied provenances in these variables. Our results confirm that A. chilensis is a drought-avoidance species, and suggest that phenotypic morphological differentiation between populations allows the species to survive throughout its broad distribution.
\end{abstract}

pressure-volume curves / xylem cavitation / stomatal conductance / drought avoidance / water stress

Résumé - Relations hydriques au niveau de la feuille et du plant chez un conifère de Patagonie Austrocedrus chilensis (D. Don) Pic. Ser. et Bizzarri: implications pour sa capacité à résister à la sécheresse. Des études physiologiques suggèrent que l'Austrocedrus chilensis peut survivre aux périodes de sécheresse évitant le stress hydrique grâce à une fermeture stomatique précoce. Cependant, il n'y a pas d'étude qui eut exploré d'autres mécanismes potentiels liés à la résistance ou à l'évitement de la sécheresse. Les objectifs de ce travail ont été : (1) mesurer la résistance hydraulique, la vulnérabilité à la cavitation et les relations hydriques des feuilles et (2) comparer ces caractéristiques avec celles des populations de différentes provenances. Les courbes pression-volume ont démontré que l'Austrocedrus chilensis possède un potentiel osmotique élevé à pleine turgescence, un potentiel hydrique au point de perte de turgescence, un module d'élasticité bas et qu'il ne présente pas de réglage élastique ou osmotique après la sécheresse. En comparaison avec d'autres gymnospermes, l'Austrocedrus chilensis a une résistance totale élevée mais aussi une importantee vulnérabilité à la cavitation. Nous n'avons pas trouvé de différences significatives entre les provenances étudiées dans ces variables. Nos résultats confirment que l'Austrocedrus chilensis est une espèce qui évite la sécheresse, et ils suggèrent que les changements phénotypiques entre populations permettent à cette espèce de survivre dans sa vaste distribution.

courbes pression-volume / cavitation du xylème / conductance stomatique / évitement de la sécheresse / tension hydrique

\section{INTRODUCTION}

South-American conifer Austrocedrus chilensis (D. Don) Pic. Ser. et Bizzarri grows in northwestern Patagonia, Argentina, in places with more than $2000 \mathrm{~mm}$ to less than $400 \mathrm{~mm}$ of mean annual precipitation. All along its distribution, most of the precipitation occurs during autumn and winter determining a drought period during summer. Austrocedrus chilensis is considered one of the most drought tolerant tree species of Patagonian region (e.g. [9]), and therefore, it is the most conspicuous species in Patagonian steppe. Across this region, survival of young trees is highly correlated to shrub presence suggesting the phenomenon known as "nurse syndrome" [9]. This syndrome is characterized by the amelioration of microenvironmental variables under a plant - the nurse - which enhances survivorship and/or growth of other species growing in association with it. Measurements of stomatal behavior of $\mathrm{A}$. chilensis have shown a drought avoidance response, with an early stomatal closure in response to vapor pressure deficit (VPD) or to soil water stress [8]. It was suggested that this highly conservative use of water may be incompatible with efficient heat dissipation by means of transpiration $[8,9]$, and that this may explain the need of a nurse plant.

Despite of the wide geographic distribution of A. chilensis, there are no large genetic differences among different provenances, not even between those with very different phenotypes

* Corresponding author: ecoforest@bariloche.inta.gov.ar 
Table I. Climatic characteristics of sites from which seeds or branches of Austrocedrus chilensis were collected (data extracted from [13]).

\begin{tabular}{|c|c|c|c|c|c|}
\hline Site & & $\begin{array}{l}\text { Latitude } \\
\text { S }\end{array}$ & $\begin{array}{c}\text { Longitude } \\
\text { W }\end{array}$ & $\begin{array}{l}\text { Altitude } \\
(\mathrm{m})\end{array}$ & $\begin{array}{l}\text { Precipitation } \\
\left(\mathrm{mm} \mathrm{year}^{-1}\right)\end{array}$ \\
\hline Pilcañeu & Xeric & $41^{\circ} 13^{\prime}$ & $70^{\circ} 42^{\prime}$ & 1100 & 330 \\
\hline Alicura & Xeric & $40^{\circ} 39^{\prime}$ & $71^{\circ} 01^{\prime}$ & 900 & 400 \\
\hline Meliquina & Mesic & $40^{\circ} 03^{\prime}$ & $71^{\circ} 10^{\prime}$ & 900 & 684 \\
\hline Catedral & Humid & $41^{\circ} 08^{\prime}$ & $71^{\circ} 27^{\prime}$ & 850 & 1350 \\
\hline Llao Llao & Humid & $41^{\circ} 03^{\prime}$ & $71^{\circ} 32^{\prime}$ & 800 & 1500 \\
\hline
\end{tabular}

nor between those exposed to opposite environments [16]. Accordingly, no differences were found in stomatal and photosynthetic response to drought between populations of $\mathrm{A}$. chilensis from humid and xeric places [8].

Mechanisms developed by trees to survive water deficits include tolerance and avoidance of tissue water stress. Avoidance of stress includes, for example, stomatal closure and changes in leaf area and orientation, while stress tolerance usually involves osmotic adjustment and also changes in elastic properties of tissues (e.g. [19]). Drought avoider species may be classified as "water spenders" or "water savers", depending on their water use $[3,15]$. These authors enumerate the following physiological characteristics as typical of water saver compared to water spender species: (1) lower osmotic potential; (2) more rigid cell walls (higher modulus elasticity); (3) less vulnerability to xylem cavitation: and (4) stronger stomatal control over transpirational water loss. On the other hand, plants species classified as water spenders have the opposite characteristics.

Despite of ecological and economical value of $A$. chilensis in Patagonian region, there are no studies that have explored potential mechanisms related to drought resistance or avoidance, except those related to stomatal behavior in saplings [8]. This information could be valuable for genetic improvement programs (as those being carried out through subsidies of National Government of Argentina), as well as to predict the response of different populations to climatic change.

Based on this background, our goal was to understand the physiological mechanisms that allow this species to survive under drought conditions. In particular, the objectives of this study were: (1) to measure hydraulic resistance of soil-to-leaf water pathway, vulnerability to xylem cavitation and leaf water relations obtained from pressure-volume curves in A. chilensis, and (2) to compare these characteristics between different provenances. Based on measured stomatal behavior [8], one of our hypotheses was that $A$. chilensis possess characteristics of water saver species. And based on genetic knowledge of the species [16] we also hypothesized that these characteristics do not differ between provenances.

In order to separate genetic from environmental influences over studied variables, we measured saplings which seeds were collected in populations representative of the environmental extremes of the species distribution. They were bred in a greenhouse in the EEA INTA Bariloche, Argentina. In addition, we carried out some of these measurements in adult plants growing in sites with climatic conditions similar to those of the saplings origin.

\section{MATERIALS AND METHODS}

The study was carried out on plants of two different ages: three years old saplings bred from seed, and adults. Saplings were produced in the tree nursery of INTA Bariloche Experimental Station (National Institute of Agricultural Technology, Argentina) from seeds collected in several locations along the precipitation gradient. For our measurements corresponding to Experiment 1 and 2 (see below), we chose plants of two provenances situated in opposite sites of this gradient (Pilcañeu - xeric site, and Catedral or Llao Llao - humid sites). Measurements or, in other cases samples, of adult trees (Experiments 1, 2 and 3) were obtained in Catedral (humid site), Meliquina (mesic site) and Alicura (xeric site). Geographical location and pluviometric characteristics of each place are shown in Table I.

\subsection{Experiment 1: Hydraulic resistance}

\subsubsection{Saplings}

For each experiment we used five individuals of $A$. chilensis of each provenance growing in a glasshouse in INTA Bariloche Experimental Station. Following [21], at the steady state, the resistance from root to

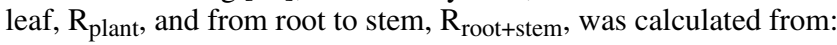

$$
\begin{gathered}
\mathrm{R}_{\text {plant }}=-(\psi \text { leaf }-\psi \text { soil }) / \mathrm{E} \\
\mathrm{R}_{\text {root+stem }}=-(\psi \text { stem }-\psi \text { soil }) / \mathrm{E}
\end{gathered}
$$

where $\psi$ soil was water potential at soil-root interface and was estimated from $\psi$ leaf measured at pre-dawn in three plants. Water potential of leaves ( $\psi$ leaf $)$ and $\psi$ stem were measured at midday in a transpiring leaf and in a nontranspiring leaf (covered with aluminum foil $2 \mathrm{~h}$ before the measurements, as was done by [21]), respectively. Water potential measurements were carried out with a Scholander-type pressure chamber (PMS Co, Corvallis, USA). Whole-plant transpiration (E) was measured with a LICOR 6200 (Licor, Nebraska, USA) using a one-liter chamber during $21 \mathrm{~s}$, immediately before water potential measurements. Due to the small size of plants, when we carried out the measurements we made these considerations in order to avoid possible negative effect of branch cutting on transpiration rate.

We applied Kruskall-Wallis ANOVA $(\alpha=0.05)$ to detect statistical differences between provenances.

\subsubsection{Adults}

Hydraulic resistance was measured in adults of A. chilensis of the mesic site (Tab. I), in four individuals in January 2001 (diameter at breast height, DAP $=28.0,30.6,34$ and $38.9 \mathrm{~cm}$ ) and in three trees in December $2001(\mathrm{DAP}=15.3,20.5,25.4 \mathrm{~cm})$. 
Whole-plant liquid phase hydraulic resistance $\left(\mathrm{R}_{\text {total }}\right)$ was estimated using the following formula:

$$
\mathrm{R}_{\text {total }}=-(\psi \text { leaf }-\psi \text { soil }) / \boldsymbol{u}
$$

where $\psi$ soil is soil water potential (estimated from predawn leaf water potential), $\psi$ leaf is leaf water potential at midday, and $\boldsymbol{u}$ was sapflow density measured between 1100 and 1200 hours (see below). Resistance of root to stem $\left(\mathrm{R}_{\text {root+stem }}\right)$ was estimated only in December 2001 as:

$$
\mathrm{R}_{\text {root }+ \text { stem }}=-(\psi \text { stem }-\psi \text { soil }) / \boldsymbol{u}
$$

where $\psi$ stem is leaf water potential measured in a branch covered with a black plastic bag and sprayed with water, $3 \mathrm{~h}$ before $\psi$ leaf measurement.

Xylem sap flux density $\left(\boldsymbol{u}, \mathrm{mL} \mathrm{cm} \mathrm{cm}^{-2} \mathrm{~min}^{-1}\right)$ was measured using $20 \mathrm{~mm}$ long continuously heated sap flow meters [5, 6]. Two pairs of sensors were installed on the south side of the trunk of each tree and covered with a radiation and rain shield to eliminate bias caused by radiation heating. Measurements were carried out every $10 \mathrm{~min}$ and stored in a datalogger (IMKO GMBH, Ettlingen, Germany) for further processing. Sample unit was each tree (average of two pairs of sensors).

\subsection{Experiment 2: Pressure-volume curves - saplings and adults}

Pressure-volume (P-V) curves were carried out during the growing season 1999-2000 using a Scholander type pressure-chamber (PMS Co, Corvallis, USA). P-V curves were conducted in little branches rehydrated to reach full turgor during a whole night. Parameters calculated were: relative water content at turgor loss point $\left(\mathrm{RWC}_{\mathrm{tlp}}\right)$, water potential at turgor loss point $\left(\psi_{1, \text { tlp }}\right)$, osmotic potential at full turgor $\left(\psi_{\pi, \text { sat }}\right)$, and bulk modulus of elasticity $(\varepsilon)$. Bulk modulus of elasticity was calculated as in [23]: $\varepsilon=\Delta \mathrm{P} / \Delta \mathrm{R}^{*}\left(\mathrm{R}^{*}{ }_{\mathrm{x}}-\mathrm{R}^{*}{ }_{\mathrm{a}}\right)$, where $\mathrm{R}^{*}{ }_{\mathrm{x}}$ is mean relative water content $\left(\mathrm{R}^{*}\right)$ over the calculation interval, $\Delta \mathrm{R}^{*}$, and $\Delta \mathrm{P}$ is the change in turgor over the same interval; $\mathrm{R}_{\mathrm{a}}$ is the relative apoplastic water content. $\mathrm{R}^{*}$ was calculated as $\left(\mathrm{W}_{\mathrm{f}}-\mathrm{W}_{\mathrm{d}}\right) /\left(\mathrm{W}_{\mathrm{t}}-\mathrm{W}_{\mathrm{d}}\right)$, where $\mathrm{W}_{\mathrm{f}}$ is the fresh weight, $\mathrm{W}_{\mathrm{d}}$ is the dry weight and $\mathrm{W}_{\mathrm{t}}$ is the turgid weight.

In adults, branches about 0.5 to $1 \mathrm{~m}$ long were collected from trees growing in humid and xeric sites (four and six individuals, respectively). Branches were placed in plastic bags to avoid desiccation during transportation.

In saplings, $\mathrm{P}-\mathrm{V}$ measurements were carried out in individuals from xeric and humid provenances in two dates: March and April. In March, we measured five well-watered saplings of each provenance. After that, the ten plants were subjected to drought conditions (no irrigation during a month) and they were re-measured in April. In the same day, other three well-watered plants of each provenance were also measured in order to separate the effect of drought from phenology.

We compared results of different provenances (in saplings) or sites (in adults) and irrigation treatments (in saplings). One-way ANOVA was used to test the difference in all parameters among provenances/ sites within each age class $(\alpha=0.05)$. ANOVA was also applied to compare April measurements within each provenance (well-watered vs. drought stressed saplings). Paired $t$ tests were applied to compare initial (before drought, March) and final (after drought, April) parameters within each provenance.

\subsection{Experiment 3: Vulnerability curve - adults}

Ten A. chilensis trees were sampled at humid, mesic and xeric sites. The final portion of a single branch per tree $(0.50$ to $1 \mathrm{~m}$ long) was harvested, wrapped in plastic black bags and brought to the laboratory.

Vulnerability to drought-induced xylem cavitation was measured as the reduction in hydraulic conductivity of a stem as a function of xylem pressure induced by air injection with a modified pressure
Table II. Whole-plant hydraulic resistance $\left(\mathrm{R}_{\text {plant }}\right)$ and resistance across root and stem ( $\left.\mathrm{R}_{\text {root+stem }}\right)$ of Austrocedrus chilensis. Values are means $\pm \mathrm{SD}$.

\begin{tabular}{lccc}
\hline Provenances/Site & & \multicolumn{2}{c}{$\begin{array}{c}\mathrm{R}_{\text {plant }} \\
\left(\mathrm{MPa} \mathrm{cm}^{2} \mathrm{~s} \mathrm{mmol}^{-1}\right)\end{array}$} \\
\hline Xeric site & Sapling & $0.338 \pm 0.257$ & $0.08 \pm 0.06$ \\
Humid site & Sapling & $0.308 \pm 0.247$ & $0.06 \pm 0.04$ \\
Mesic site (Jan. 2001) & Adult & $1.4 \pm 3.710^{-4}$ & - \\
Mesic site (Dec. 2001) & Adult & $1.7 \pm 1410^{-4}$ & $9.1 \pm 6.510^{-5}$ \\
\hline
\end{tabular}

chamber. In general, we used the same procedure described by [13]. Segments $(30 \mathrm{~cm}$ long) were excised from the branches, debarked, and all lateral branches were cut to provide an entry point for air. All these procedures were carried out under water. To determine maximum hydraulic conductivity $\left(k_{\max }\right)$ of each stem, before the induction of cavitation the segment was cleared of existing air embolism using filtered water at $170 \mathrm{kPa}$ during one hour. Percent loss in conductivity (PLC) following each chamber pressurization was calculated as PLC $=$ $100\left(\left(k_{\max }-k_{h}\right) / k_{\max }\right)$, were $k_{h}$ is hydraulic conductivity of the segment measured after each chamber pressurization.

Vulnerability curves were fitted with an exponential sigmoid equation (following [13]):

$$
\mathrm{PLC}=100(1+\exp (a(\psi-b)))
$$

where $\psi$ is the negative of injection pressure, $a$ is a measure of the degree to which conductivity responds to injection pressure (curve shape) and $b$ represents $\psi$ at which a $50 \%$ loss in conductivity occurs (curve displacement along the $x$-axis). Vulnerability curves for trees from xeric and humid sites were carried out during December, while those of trees from the mesic site were carried out in March.

In order to compare parameter values of vulnerability curves between populations of $A$. chilensis, we applied T tests with $\alpha=0.05$.

\section{RESULTS}

\subsection{Experiment 1: Hydraulic resistance}

No differences were found between saplings of different provenances in total and partial resistances $(P>0.05$, Tab. II). $\mathrm{R}_{\text {roots+stem }}: \mathrm{R}_{\text {total }}$ ratio was higher in adults $(0.55)$ than in saplings (0.23). Therefore, $45 \%$ of the total resistance occurs at the leaf level in adult trees while in saplings $\mathrm{R}_{\text {leaf }}$ represents more than $70 \%$ of total resistance. Predawn water potential ( $\psi$ soil) of adults was -0.48 (SD \pm 0.03 ) MPa for 2000-2001 season and -0.47 (SD \pm 0.15$) \mathrm{MPa}$ for 2001-2002 season. Water potential at midday ( $\psi$ leaf) was $-1.24(\mathrm{SD} \pm 0.13) \mathrm{MPa}$ and -1.18 (SD \pm 0.06$) \mathrm{MPa}$ for 2000-2001 and 2001-2002 season, respectively.

\subsection{Experiment 2: Pressure-volume curves}

\subsubsection{Saplings}

Table III shows mean values of parameters estimated from $\mathrm{P}-\mathrm{V}$ curves. No differences between provenances were 
Table III. Mean $( \pm \mathrm{SD})$ value of relative water content at turgor loss point $\left(\mathrm{RWC}_{\mathrm{tlp}}\right)$, water potential at turgor loss point $\left(\psi_{1, \mathrm{tlp}}\right.$; MPa), osmotic potential at full turgor $\left(\psi_{\pi, \mathrm{sat}} ; \mathrm{MPa}\right)$ and bulk modulus of elasticity $(\varepsilon, \mathrm{MPa})$ measured in Austrocedrus chilensis saplings and adults.

\begin{tabular}{|c|c|c|c|c|c|c|c|}
\hline Sites & Age & $\mathrm{RWC}_{\mathrm{tlp}}$ & $\psi 1$, tlp & & $\psi_{\text {sat }}$ & $\mathrm{e}$ & \\
\hline Humid & Sapling\# & $0.82 \pm 0.06$ & $-1.10 \pm 0.22$ & & $-0.72 \pm 0.21$ & $1.16 \pm 0.11$ & $\boldsymbol{A}$ \\
\hline Humid & Sapling** & $0.80 \pm 0.08$ & $-1.91 \pm 0.09$ & $\boldsymbol{\uparrow}$ & $-1.25 \pm 0.14$ & $2.94 \pm 0.10$ & \\
\hline Humid & Sapling* & $0.77 \pm 0.05$ & $-1.22 \pm 0.24$ & $\nabla$ & $-0.83 \pm 0.15$ & $2.93 \pm 0.68$ & $\nabla$ \\
\hline Humid & Adults & $0.82 \pm 0.13 \mathrm{a}$ & $-1.53 \pm 0.32 \mathrm{a}$ & & $-1.05 \pm 0.20 \mathrm{a}$ & $2.75 \pm 0.82 \mathrm{a}$ & \\
\hline Xeric & Sapling\# & $0.76 \pm 0.09$ & $-1.10 \pm 0.20$ & & $-0.55 \pm 0.20$ & $0.91 \pm 0.34$ & $\boldsymbol{A}$ \\
\hline Xeric & Sapling** & $0.81 \pm 0.03$ & $-1.70 \pm 0.29$ & $\boldsymbol{A}$ & $-1.03 \pm 0.42$ & $1.88 \pm 0.69$ & \\
\hline Xeric & Sapling* & $0.76 \pm 0.04$ & $-1.10 \pm 0.35$ & $\nabla$ & $-0.68 \pm 0.31$ & $2.00 \pm 0.70$ & $\nabla$ \\
\hline Xeric & Adult & $0.86 \pm 0.03 \mathrm{a}$ & $-1.25 \pm 0.32 \mathrm{a}$ & & $-0.68 \pm 0.20 b$ & $0.64 \pm 0.19 b$ & \\
\hline
\end{tabular}

\# Initial condition of the individuals (well irrigated, measurements in March), * with and ** without drought period (measurements in April). Arrows indicate significant differences between sapling groups (paired $t$ test or ANOVA, $P<0.05$ ). Different letters indicate statistical differences between adult plants of different sites (ANOVA $P<0.05$ ).

observed in any of the estimated parameters $(P>0.05)$. Considering well-watered plants, $\psi_{\pi \text {,sat }}$ was above $-0.75 \mathrm{MPa}$ in March and above $-1 \mathrm{MPa}$ in April; $\psi_{1, \text { tlp }}$ was around $-1.1 \mathrm{MPa}$ in March and close to $-1.8 \mathrm{MPa}$ in April; $\mathrm{RWC}_{1, \text { tlp }}$ was always around 0.80 and e was around $1 \mathrm{MPa}$ in March and increased above $2 \mathrm{MPa}$ in April (Tab. III).

In the irrigation experiment, no osmotic adjustment was observed after the desiccation period $\left(\psi_{\pi \text {,sat }}\right.$ was similar between dates, $P>0.05)$. In addition, $\psi_{1, \text { tlp }}$ and $\mathrm{RWC}_{1, \text { tlp }}$ showed no changes after the drought period (April) compared to initial values (March, $P>0.05$, Tab. III). On the contrary, a significant increase in $\varepsilon$ was observed in the same plants between dates $(P<0.05$, Tab. III). However, similar values of $\varepsilon$ were also observed in well-watered plants measured in April, indicating that this increment in $\varepsilon$ was not due to irrigation treatment as was also reported in other species [3, 23].

\subsubsection{Adults}

Significant differences were detected between adults from both sites in $\psi_{\pi \text {,sat }}$ and $\varepsilon\left(P<0.05\right.$, Tab. III). A lower $\psi_{\pi \text {,sat }}$ and a higher $\varepsilon$ were estimated in plants of the humid site compared to those of the xeric place. No differences between sites were detected in $\psi_{1, \text { tlp }}$ nor $\mathrm{RWC}_{1, \text { tlp }}(P>0.05$, Tab. III).

\subsection{Experiment 3: Vulnerability curve}

We found significant differences $(P<0.05)$ in the shape of vulnerability curve between trees from the mesic site compared to plants of the other two sites (Tab. IV). However, pressure at which a $50 \%$ loss in conductivity occurs estimated for the three sites was the same (Fig. 1, $P>0.05$ ), with a mean value of $-2.12 \mathrm{MPa}$ (Tab. IV). Maximum conductivity of the stems $\left(k_{\max } \pm \mathrm{SD}\right)$ was the same for trees from humid and xeric sites $\left(7.20 \pm 0.66\right.$ and $7.79 \pm 0.45 \mathrm{~kg} \mathrm{~m}^{-1} \mathrm{MPa}^{-1} \mathrm{~s}^{-1}$, respectively) and lower $(P<0.05)$ for the mesic site $\left(4.34 \pm 0.67 \mathrm{~kg} \mathrm{~m}^{-1}\right.$ $\left.\mathrm{MPa}^{-1} \mathrm{~s}^{-1}\right)$. Differences between plants of the mesic site and those of the other two sites could be related to differences in sampling period [21] and/or genetic differences.
Table IV. Mean ( \pm SD) slopes $(a)$ and intercepts $(b)$ of equation, fitted to vulnerability curves of Austrocedrus chilensis adults from different sites. Different letters indicate significant differences in each parameter between sites ( $T$ tests, $\alpha=0.05$ ).

\begin{tabular}{lcccc}
\hline Site & $\mathrm{a}$ & \multicolumn{1}{c}{$b(\mathrm{MPa})$} & $R^{2}$ adj. & $F$-value \\
\hline Humid & $1.56( \pm 0.20) \mathrm{a}$ & $-2.07( \pm 0.08) \mathrm{a}$ & 0.87 & 215.21 \\
Mesic & $0.83( \pm 0.09) \mathrm{b}$ & $-2.19( \pm 0.11) \mathrm{a}$ & 0.88 & 197.023 \\
Xeric & $1.18( \pm 0.13) \mathrm{a}$ & $-2.13( \pm 0.10) \mathrm{a}$ & 0.89 & 255.577 \\
$\begin{array}{l}\text { Combined } \\
\text { (pooled data) }\end{array}$ & $1.14( \pm 0.08)$ & $-2.12( \pm 0.06)$ & 0.86 & 593.279 \\
\hline
\end{tabular}

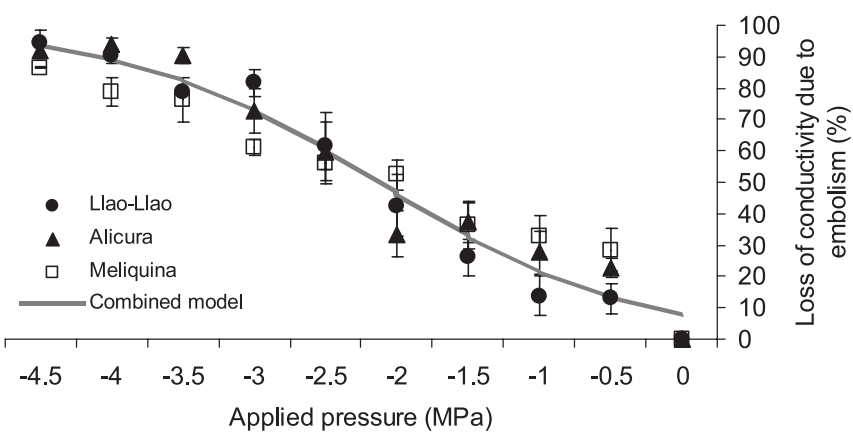

Figure 1. Vulnerability curves of stems of Austrocedrus chilensis trees growing in three sites contrasting in precipitation level (see Tab. I). See Table IV for parameters of each regression model.

\section{DISCUSSION}

Accordingly to previous genetic [16] and physiological studies [8], we did not detect differences between provenances/ sites in leaf water relations, hydraulic resistance, nor vulnerability to xylem cavitation. These results support partially our initial hypothesis. 
However, our results do not agree with previously proposed physiological characteristics of water saver plants $[3,15]$. In spite of $A$. chilensis having a strong stomatal control, limiting probably its establishment to nurse plants $[8,10]$, it did not present the other characteristics of water saver plants. On the contrary, A. chilensis showed typical values of water spender species [3] in relation to osmotic potential, water potential and cell water content at turgor loss point, hydraulic resistance and vulnerability to xylem cavitation.

Low values of water potential at which cells of $A$. chilensis loose turgor (around -1.3 MPa in adult plants) agree with midday leaf water potentials measured under field conditions (around $-1.2 \mathrm{MPa}$ ). Preliminary stomatal conductance measurements carried out under the same field conditions indicated that $A$. chilensis closes its stomata early in the morning in order to maintain high leaf water potentials [8]. Compared with other species (e.g. [3, 23]), $\varepsilon$ values of $A$. chilensis are very low, suggesting high cell wall elasticity. As in water spender species, this characteristic is correlated with a high $\psi_{\pi \text {,sat }}$, both of which would impede them to extract soil water efficiently and to recover from leaf water deficit easily under low soil water availability [3]. In addition, we did not detect osmotic or elastic adjustments after the drought experiment as was predicted for drought avoidance species [19]. As a whole, results from P-V curves suggest that $A$. chilensis has typical parameters of water spender species. However, the strong stomatal control of transpiration prevents such a behavior in relation to water use [8].

Hydraulic resistance $\left(\mathrm{R}_{\text {plant }}\right)$ of $A$. chilensis saplings was higher than $\mathrm{R}_{\text {plant }}$ of the riparian species Acer saccharinum $\mathrm{L}$. (0.018 $\left.\mathrm{MPa} \mathrm{cm}^{2} \mathrm{~s} \mathrm{mmol}^{-1},[21]\right)$. Also, $\mathrm{R}_{\text {plant }}$ of $A$. chilensis saplings was higher than several provenances of $P$. halepensis Mill. [16, 20]. However, the $\mathrm{R}_{\text {stem+root }}: \mathrm{R}_{\text {plant }}$ ratio found in $A$. chilensis were lower than those found in that species (approximately $80 \%$, respectively, [21]). Total resistance measured in A. chilensis adults was higher than that measured in $P$. ponderosa trees growing in the same place $\left(1.210^{-4}\right.$ to $9.410^{-5} \mathrm{MPa}$ $\mathrm{cm}^{2} \mathrm{~s} \mathrm{mmol}^{-1}$, Meliquina, Patagonia Argentina; [7]) or $P$. ponderosa growing in USA $\left(6.11^{-5} \mathrm{MPa} \mathrm{cm}^{2} \mathrm{~s} \mathrm{mmol}^{-1}\right.$ [11]). Compared to several European Mediterranean tree species, $\mathrm{R}_{\mathrm{plant}}$ of $A$. chilensis was also higher $\left(2.910^{-5}\right.$ to $410^{-4} \mathrm{MPa}$ $\left.\mathrm{cm}^{2} \mathrm{~s} \mathrm{mmol}-1,[14]\right)$, as well to other six Pinacea species of northern hemisphere [18]. In spite of this high resistance, vulnerability to cavitation of $A$. chilensis was higher than that reported for $P$. ponderosa $[13,18]$ and other Mediterranean species except Quercus ilex [14]. This last species was catalogued as a drought avoider species [4], and shares with A. chilensis a high stomatal control of transpiration and high vulnerability to cavitation (but see Tyree and Cochard [22] who found contrasting results about vulnerability to cavitation in that Quercus species). Our results in saplings and adults indicate that the high $\mathrm{R}_{\text {plant }}$ is mainly located at the leaf level. Based on the classification proposed by Cruiziat et al. [2], A. chilensis belongs to the group of trees that control extension of embolism by stomatal closure. This was also observed in many species such as $P$. sylvestris L. [17, 18], Q. petraea [1] and Picea abies (L.) Karst. [12]. In this group of trees the value of $\psi_{x y l e m}$ which provokes $10 \%$ loss of hydraulic conductivity also lead to a $90 \%$ of stomatal closure.

In conclusion, these and previous results [8] demonstrate that the main physiological mechanism that allow A. chilensis to survive water deficits is its strong stomatal control. This species has no additional mechanisms, such as osmotic or elastic adjustment, or a low vulnerability to xylem cavitation, at the leaf or xylem levels, which can help it to tolerate drought periods. In contrast, its high $\psi_{1, \mathrm{tlp}}, \psi_{\pi \text {,sat }}$ and $\psi$ at which looses $50 \%$ of xylem conductivity, suggest that it is a species that evolved without drought stress, but it is currently exposed to limiting conditions. These results allow us to suppose that the main mechanism of $A$. chilensis that permit its broad geographic distribution may be related with changes at morphological whole plant level, such as in the ratio leaf area / sapwood area, as was proposed for other species (e.g. [13]).

Acknowledgements: This research was partially funded by INTA (National Institute for Agricultural Technology) and SECyT through the project PICT 08-09415. M.E. Fernández was supported by a fellowship for graduate students of CONICET. We also thank the support of the Genetics Group of INTA EEA Bariloche, which provided the plants for the experiments. We also thank two anonymous reviewers for their valuable comments.

\section{REFERENCES}

[1] Cochard H., Bréda N., Granier A., Whole tree hydraulic conductance and water loss regulation of Quercus petraea during drought: evidence for stomatal control of embolism? Ann. Sci. For. 53 (1996) 197-206.

[2] Cruiziat P., Cochard H., Améglio T., Hydraulic architecture of trees: main concepts and results, Ann. For. Sci. 59 (2002) 723-752.

[3] Dong X., Zhang X., Some observations of the adaptations of sandy shrubs to the arid environments in the Mu Us Sandland: leaf water relations and anatomic features, J. Arid Environ. 48 (2001) 41-48.

[4] Fotelli M.N., Radoglou K.M., Constantinidou H.-I.A., Water stress responses of seedlings of four Mediterranean oak species, Tree Physiol. 20 (2000) 1065-1075.

[5] Granier A., Une nouvelle méthode pour la mesure du flux de sève brute dans le tronc des arbres, Ann. Sci. For. 42 (1985) 193-200.

[6] Granier A., Evaluation of transpiration in a Douglas-fir stand by means of sapflow measurements, Tree Physiol. 3 (1987) 309-320.

[7] Gyenge J.E., Fernández M.E., Schlichter T.M., Water relations of ponderosa pines in Patagonia Argentina: implications for local water resources and individual growth, Trees 17 (2003) 147-423.

[8] Gyenge J.E., Uso De Agua y resistencia a la sequía de Pino Ponderosa y Ciprés de la Cordillera, Universidad Nacional Del Comahue, Centro Regional Universitario Bariloche, Doctoral thesis (in revision by the Academic Committee).

[9] Kitzberger T., Fire regime variation along a northern Patagonian forest-steppe gradient: stand and landscape responses, Ph.D. thesis, Department of Geography, Univ. Colorado, Colorado, USA, 1995, pp. 1-203.

[10] Kitzberger T., Steinaker D.F., Veblen T.T., Effects of climatic variability on facilitation of tree establishment in Northern Patagonia, Ecology 81 (2000) 1914-1924.

[11] Kolb T.E., Stone J.E., Differences in leaf gas exchange and water relations among species and tree sizes in an Arizona pine-oak forest, Tree Physiol. 20 (2000) 1-2.

[12] Lu P., Biron P., Granier A., Cochard H., Water relations of adults Norway spruce (Picea abies (L.) Karst.) under soil drought in the Vosges mountains: whole tree hydraulic conductance, xylem embolism and water loss regulation, Ann. Sci. For. 53 (1996) 113-121. 
[13] Maherali H., DeLucia E.H., Xylem conductivity and vulnerability to cavitation of ponderosa pine growing in constrasting environments, Tree Physiol. 20 (2000) 859-867.

[14] Martínez-Vilalta J., Prat E., Oliveras I., Piñol J., Xylem hydraulic properties of roots and stems of nine Mediterranean woody species, Oecologia 133 (2002) 19-29.

[15] Monson R.K., Smith S.D., Season water potential components of Sonoran desert plants, Ecology 63 (1982) 113-123.

[16] Pastorino M.J., Genetic variation and reproduction system of Austrocedrus chilensis (D. Don) florin et Boutelje, a cypress endemic to the Andean-Patagonian Forest, Ph.D. thesis, Cuvillier Verlag, Göttingen, Germany, 2000, pp. 1-165.

[17] Perks M., Irvine J., Grace J., Xylem acoustic signals from mature Pinus sylvestris during an extended drought, Ann. For. Sci. 61 (2004) 1-8.

[18] Piñol J., Sala A., Ecological implications of xylem cavitation for several Pinaceae in the Pacific Northern USA, Funct. Ecol. 14 (2000) 538-545.
[19] Torrecillas A., Alarcón J.J., Domingo R., Planes J., SánchezBlanco M.J., Strategies for drought resistance in leaves of two almond cultivars, Plant Sci. 118 (1996) 135-143.

[20] Tognetti R., Michelozzi M., Giovannelli A., Geographical variation in water relations, hydraulic architecture and terpene composition of Aleppo pine seedlings from Italian provenances, Tree Physiol. 17 (1997) 241-250.

[21] Tsuda M., Tyree M.T., Whole-plant hydraulic resistance and vulnerability segmentation in Acer saccharinum, Tree Physiol. 17 (1997) 351-357.

[22] Tyree M.T., Cochard H., Summer and winter embolism in oak: impact on water relations, Ann. Sci. For. 53 (1996) 173-180.

[23] White D.A., Beadle C.L., Worledge D., Leaf water relations of Eucalyptus globulus ssp. globulus and E. nitens: seasonal, drought and species effects, Tree Physiol. 16 (1996) 469-476. 